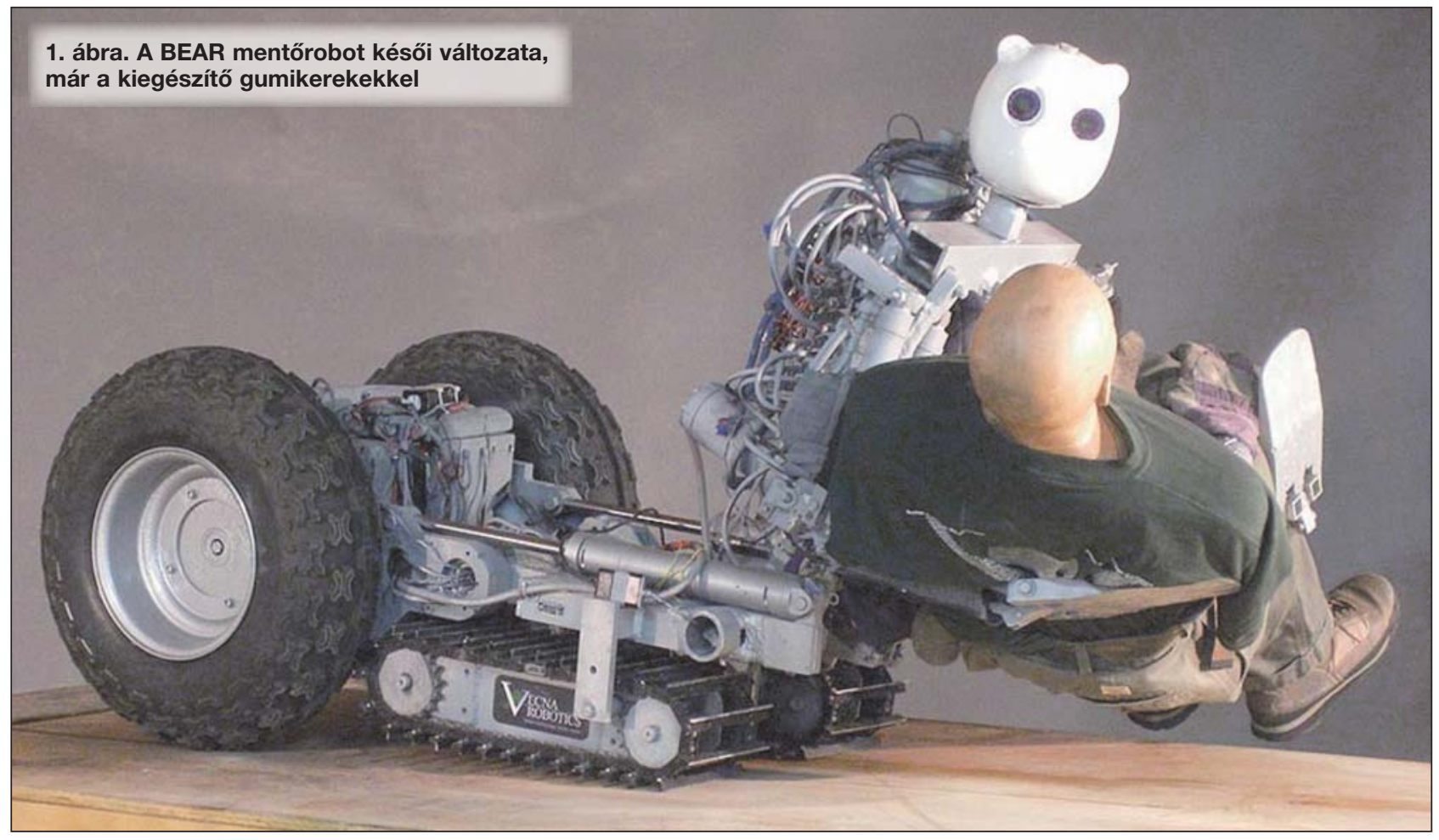

Brányi Bence*

\title{
A BEAR katonai mentőrobot-fejlesztési
} program

\section{Bevezetés}

A súlyosan sérült, gyakran mozgásképtelen, esetleg eszméletlen katonák kimentése a harctérről kulcsfontosságú feladat, lévén az állapotuk gyors stabilizálása és megfelelő ellátás hiányában a halálozási arány meredeken emelkedhet. Ennek elkerülésére hozták létre az olyan tábori kórházhálózatokat, mint az Amerikai Egyesült Államok 1945-től használt MASH (Mobile Army Surgical Hospital) rendszerét, illetve modern utódját, a CSH (Combat Support Hospital) rendszert. A frontsebészet rendkívül hatékony - már a Vietnámi háború alatt is csupán 2,6\% volt a MASH sátorkórházaiba eljuttatott katonák halálozási aránya, amit mára sikerült tovább javítani.

Praktikusan ez azt jelenti, hogy a kérdés már nem az, hogy a katona túlélheti-e a sérülését, hanem az, hogy sikerül-e időben eljuttatni a front mögötti tábori orvosokhoz.
Jelenleg a szanitécek, vagy hiányukban az egység többi tagjának felelőssége a sérült katona állapotának stabilizálása, majd kimentése, ám ez rendkívül veszélyes és megterhelő feladat, mert a felszereléssel együtt több mint 100 kg-os testet kell egy-két katonának mozgatni, sok esetben ellenséges tűzben.

Az egészségügyi katonák munkáját a jövőben hatékonyan segíthetik olyan mentőrobotok, amelyek akár ütközet közben, tűz alatt tartott terepszakaszról is képesek a sebesülteket önállóan kimenteni és eljuttatni a legközelebbi mentőjármúig vagy tábori kórházig. Ez azért is fontos, mert a páncélozott mentőjármúvek - legyenek azok gumikerekes, vagy akár lánctalpas eszközök - sok esetben nem képesek a városi vagy sűrü növényzet borította terepen megközelíteni a sebesültet. Egy ilyen mentőrobot képességeit, lehetséges fejlesztési irányát demonstrálta a Vecna társaság BEAR projectje.
ÖSSZEFOGLALÁS: Néhány év múlva már realitás lehet a harcmezőn, hogy robotok viszik ki a sebesülteket a veszélyzónákból. Az egyik legkorábbi, tesztelt prototípusok közé tartozik az Amerikai Egyesült Államok hadereje számára fejlesztett BEAR System (Battlefield Extraction-Assist Robot.)

KULCSSZAVAK: robot, mentőrobot, Vecna BEAR, Amerikai Egyesült Államok, haditechnikai kutatás-fejlesztés
ABSTRACT: A few years later there may be realities that on the battlefield robots are taking the wounded from the danger zones. One of the earliest tested prototypes is the BEAR System (Battlefield Extraction-Assist Robot) developed for the United States.

KEY WORDS: robot, rescue robot, Vecna BEAR, United States, military technology research and development 


\section{A FEJLESZTŐ}

Az amerikai Vecna Technologies vállalatot 1998-ban alapították Cambridge városában (Massachusetts állam, Amerikai Egyesült Államok). A cég kettős profillal rendelkezik: kezdetben egészségügyi felügyeleti rendszereket fejlesztettek, amelynek kapcsán az amerikai hadsereg már leszerelt és még aktív állományának, valamint családtagjaiknak egészségügyi ellátást biztosító Military Health System-nek is dolgoztak.

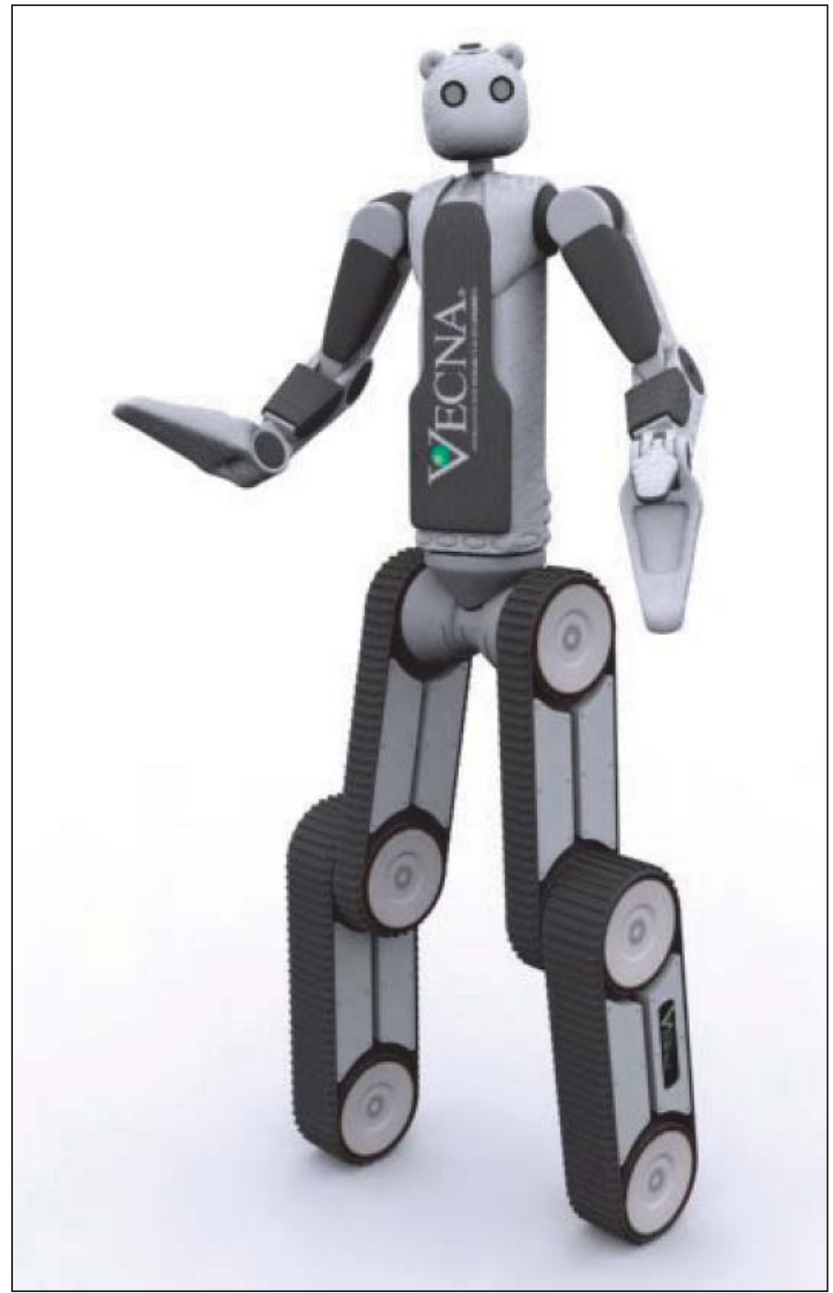

2. ábra. Korai koncepciós ábra a mentőrobotról - már ezen a változaton is látható a BEAR három állásban rögzíthető kialakítása

1. táblázat. A BEAR mentőrobot föbb elemei
A Vecna ezen tevékenységét máig végzi, de emellett létrehozták a Vecna Robotics-ot, amely többféle autonóm teherszállító robotot tervez és gyárt egészségügyi, illetve logisztikai feladatokra. A Vecna a két eltérő tevékenységét egyesítve alkotta meg a Battlefield Extraction-Assist Robot-ot, azaz a harctéri mentés-támogató robotot, röviden BEAR harctéri mentőrobotot. (Az angol betűszó magyarul medvét jelent. A robot fejrésze is medvearcot formáz.)

\section{A MENTŐROBOT MÜKÖDÉSE}

Relatív kis mérete lehetővé teszi a BEAR számára, hogy a harcoló alakulattal együtt kerüljön bevetésre (ennek érdekében a robotokat a harcjármüben, vagy azon kívül is el lehet helyezni, illetve a mögött vontatni).

A BEAR mentőrobot dimenziói összemérhetők egy emberével, de az eszköz végletekig leegyszerűsítve, egy villástargoncához hasonló. Miután a BEAR megközelítette a sebesültet, hidraulikus szállító-karjait óvatosan a sebesült térde, és háta alá csúsztatva felemeli a katonát, majd maga előtt tartva eljuttatja a közelben várakozó harcjárműhöz. A katona ellátására már a jármü belső terében kerülhet sor.

A karok terhelhetősége 227 kg (500 font) és egymástól függetlenül vezérelhetők, ezáltal a robot a katonát teljes felszereléssel együtt mentheti ki. A BEAR emellett képes egyik kezével felemelni egy gerendát vagy fatörzset, miközben a másikkal kihúzhatja az alatta fekvő katonát. A mentőrobot „kezei”, karja és törzse nyomásérzékelőkkel vannak ellátva, ezért jelentős erőkifejtésre képes, de a sebesülttel óvatosan bánik.

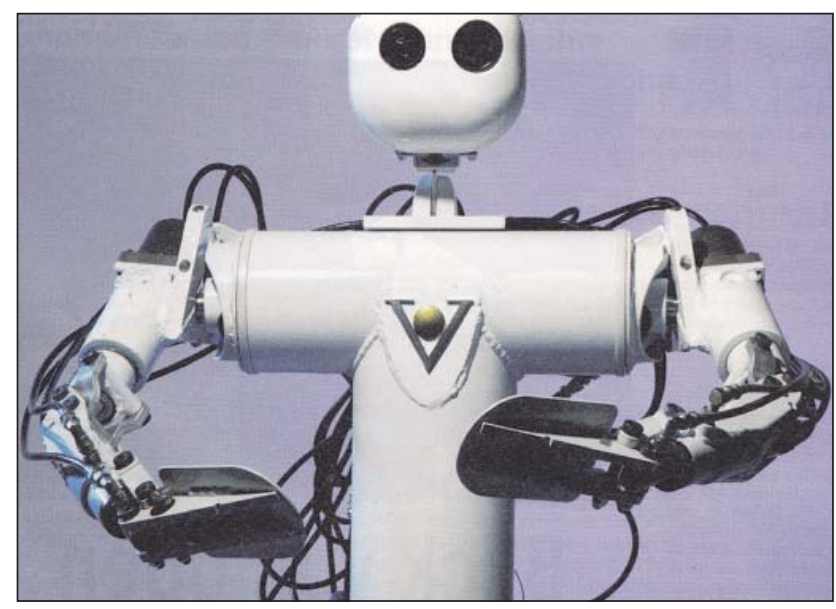

3. ábra. Az amerikai BEAR katonai mentőrobot prototípusának fogókarjai

\begin{tabular}{|l|l|}
\hline Kialakítás & $\begin{array}{l}\text { Az acélból (részben titánból) gyártott BEAR magassága 1,85 méter, szélessége 0,61 méter, } \\
\text { hossza 0,25 méter, saját tömege } 140 \text { kilogramm. A robot elektromos meghajtású, } \\
\text { akkumulátorai a mell- és hátlap között találhatók. A BEAR egy feltöltéssel 1-2 órát üzemelhet. }\end{array}$ \\
\hline Fej & $\begin{array}{l}\text { A „fejet” két kamerával és mikrofonokkal látták el, segítségükkel a robot képes felmérni a } \\
\text { környezetét. }\end{array}$ \\
\hline Felsőtest & A karok hidraulikus mozgatásúak, teljesítményük 2200 Watt. \\
\hline Futómű & $\begin{array}{l}\text { A futómű a kezdeti változatoknál két párhuzamos elemből állt, amelyet két-két kettős } \\
\text { tagoltságú, módosítható állásszögú lánctalp alkotott, ami kipróbált és tűzszerész robotokon } \\
\text { bevált megoldás. }{ }^{1} \text { A BEAR késői változatának végsebessége eléri az óránkénti 19 km-t. }{ }^{2}\end{array}$ \\
\hline Egyensúlyrendszer & $\begin{array}{l}\text { A „dinamikus egyensúlyrendszer” biztosítja, hogy a robot minden helyzetben megtartsa az } \\
\text { egyensúlyát, sebesültszállítás közben is. }\end{array}$ \\
\hline
\end{tabular}


A mentőrobot futóművét eredetileg két pár, egyenként két részből álló lánctalp alkotta, ezt idővel két nagyméretű kerék és egy lánctalp párosával váltották le, növelve az eszköz sebességét. A BEAR robotot a késői változatokban egy kiegészítő páncélzat védi a gránátszilánkoktól.

\section{FLEXIBILIS KIALAKÍTÁS}

A BEAR különleges, háromállású kialakítása lehetővé teszi, hogy minden helyzetben a bevetési feltételeknek megfelelő tartást vehessen fel.

A bevetés első szakaszán a robot felépítményét előredönti, a sebesültet a talaj közelében tartva, növelve a katona és az eszköz túlélési esélyét tűzharc során (a BEAR önvédelmi fegyverzettel nem rendelkezik). Erdőn történő áthaladásnál, vagy védettebb mögöttes terepszakaszon a robot függőlegesre állíthatja a futóművét („felállhat”), növelve ezzel a szállítási magasságot és sebességet.

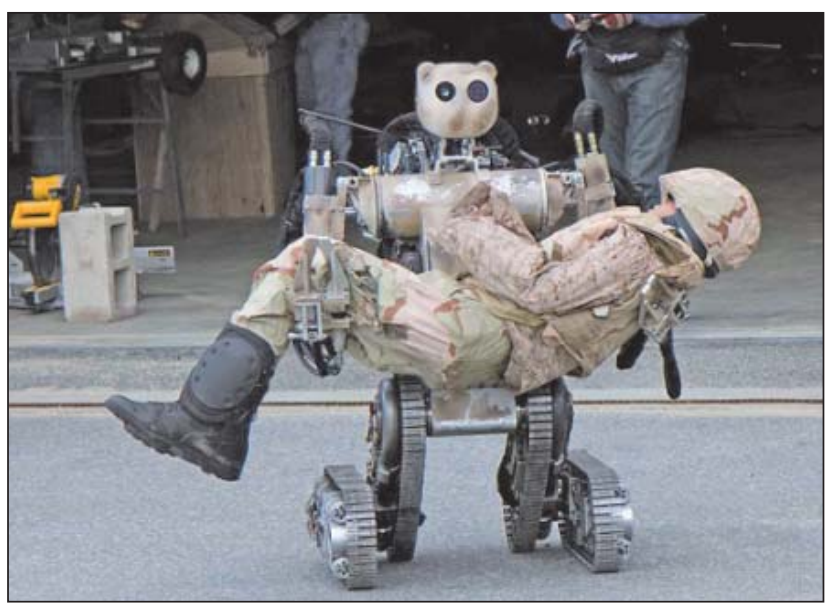

4. ábra. Felegyenesedett helyzetben szállít sebesültet a BEAR katonai mentörobot (korai változat, még két pár két tagból álló lánctalppal

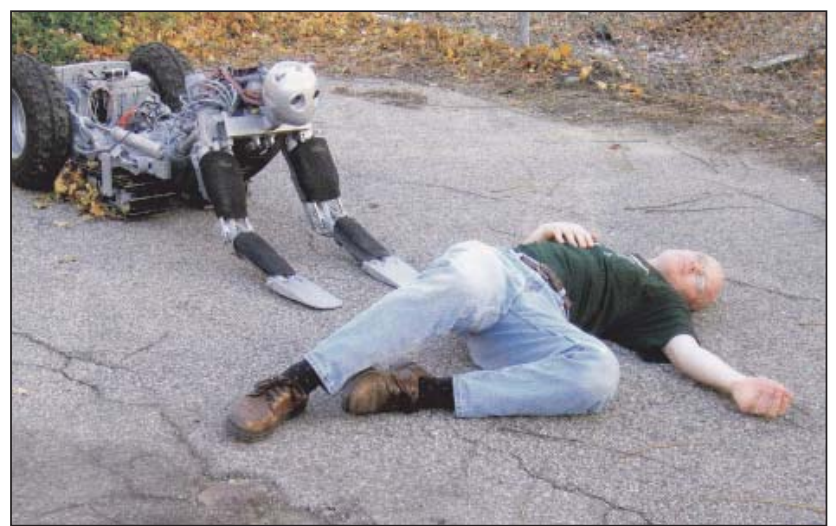

5. ábra. A BEAR mentőrobot felkészül sebesült felemelésére

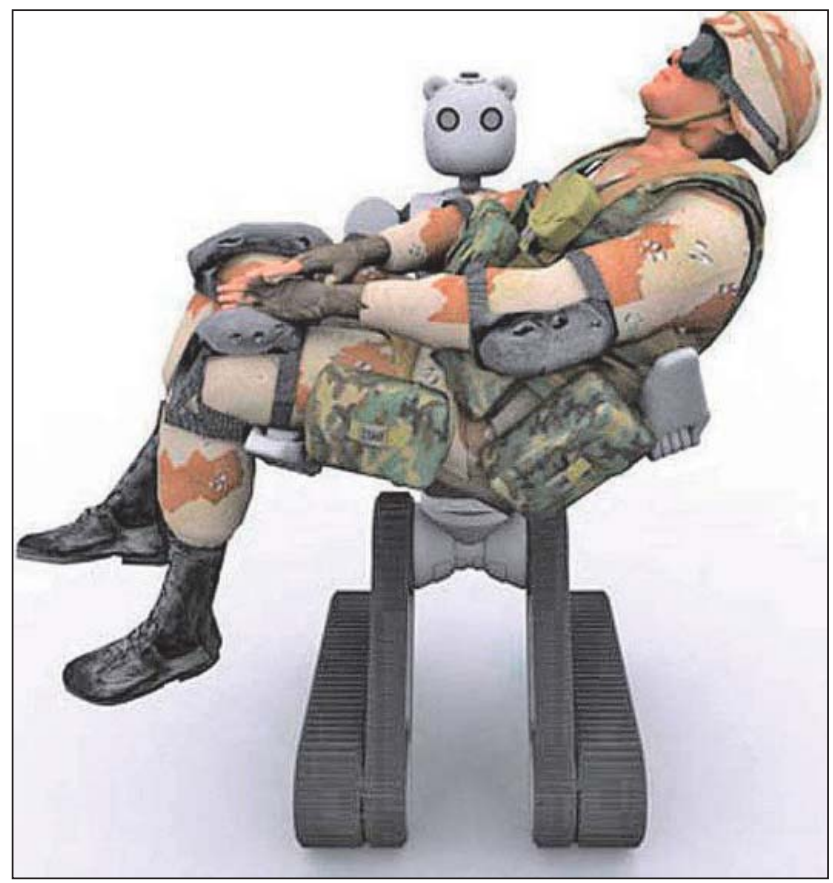

6. ábra. A BEAR mentőrobot teljes felszerelésű katona szállítására is képes

Ez a flexibilitás és az antropomorf forma lehetővé teszi a robot számára, hogy a legtöbb olyan helyen el tudjon menni, ahol egy ember is el tud; ajtón, folyosón keresztül vagy fák között, és járművek alatt is. A robot képes felmenni lépcsőn, illetve a kilincset lenyomva ajtókat nyithat ki.

A robot korlátozott mértékben önállóan is végezheti a feladatát, de szükség esetén egy katona bármikor átveheti az eszköz irányítását. A BEAR-hez terveztek egy, az M4-es gépkarabélyra erősíthető irányítórendszert (Mounted Force Controller), illetve egy, a katona felszerelésére rögzíthető irányítórendszert (iGlove), ezáltal az irányításhoz nincs szükség külön kezelőre.

\section{A MENTŐROBOT FEJLESZTÉSE}

A BEAR-t Daniel Theobald, a Vecna Technologies vezérigazgatója 2005-ben, a US Air Force Cambridge Research Laboratories (az amerikai légierő cambridgei kutató-laboratóriumában) kezdte tervezni. A mentőrobot fejlesztéséhez szükséges keretet kezdetben a Vecna saját forrásból teremtette elő, később az amerikai hadsereg és a DARPA (az Amerikai Egyesült Államok Védelmi Minisztériumának kutatásért felelős részlege) is bekapcsolódott a finanszírozásba, majd 2007-ben a program 1 millió dollár értékű állami támogatásban részesült (a teljes fejlesztési költség legalább 30 millió dollár volt). A robot fejlesztése során legalább 9 iterációt élt meg, a kezdeti, kizárólag demonstrációs célú eszközt fokozatosan fejlesztve ${ }^{3}$ a végleges változatig.

\section{2. táblázat. A BEAR mentőrobot tartásformái}

\begin{tabular}{|l|l|}
\hline Egyenes tartás & $\begin{array}{l}\text { A mentőrobot „felegyenesedve” halad, ezáltal nagyobb sebességre képes. A számítógép- } \\
\text { vezérelt egyensúlyrendszerrel biztosan tartja a terhet a karjaiban. }\end{array}$ \\
\hline Középmagas tartás & $\begin{array}{l}\text { A robot az „alsó lábszárának” megfelelő hernyótalpain halad, felépítményét függőlegesen } \\
\text { tartja, ezáltal magasságát több mint felére csökkenti. }\end{array}$ \\
\hline Vízszintes tartás & $\begin{array}{l}\text { A robot a futómúvére ülve halad, felépítményét vízszintesen, a talajjal párhuzamosan tartja. } \\
\text { A sebesültet szintén talajközelben tartva, kisebb célt mutat. }\end{array}$ \\
\hline
\end{tabular}




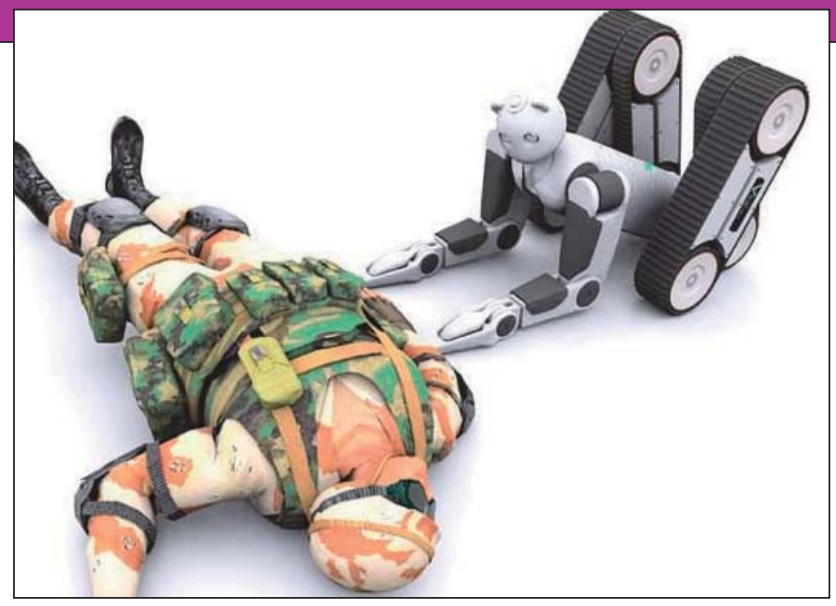

7. ábra. Korai koncepció a BEAR mentőrobotról, ahogy felkészül a sérült katona emelésére

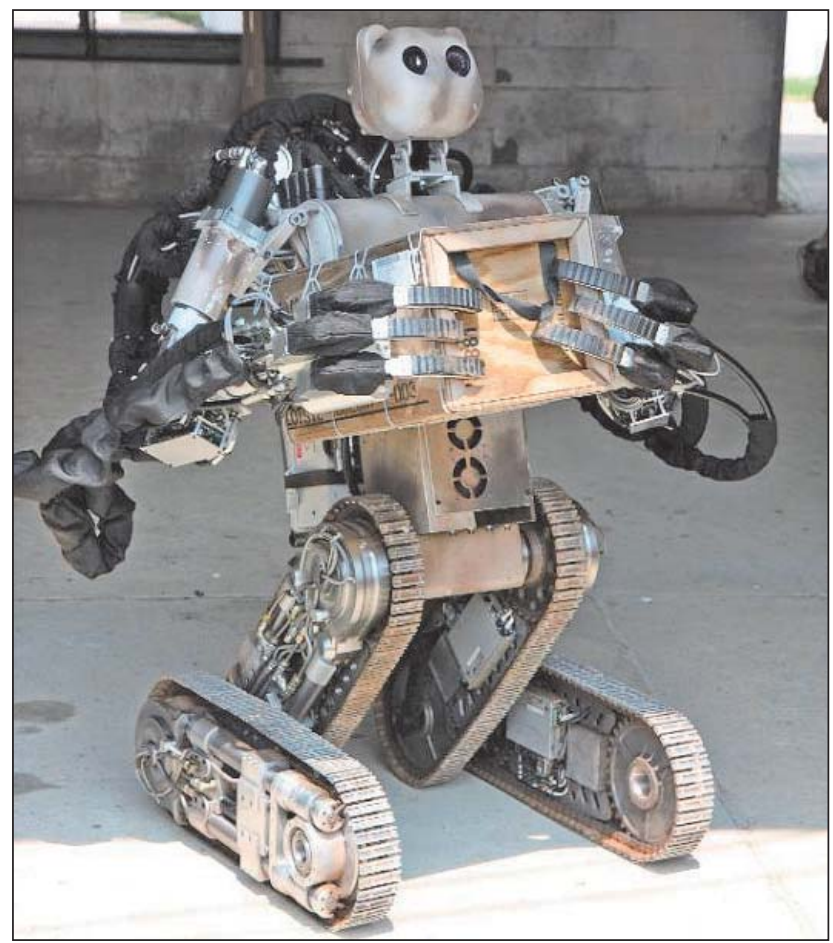

8. ábra. A BEAR korai változata, még páncélzat nélküli alumínium vázzal és többcélú fogókarokkal

A mentőrobotot az amerikai hadsereg tesztelte (többek között a Georgiában található Infantry Centre Manoeuvre Battle Laboratory-ban). Az eszköz fejlesztése 2011-ig követhető, akkor azonban megszakadt (valószínűleg nem függetlenül a légierőnek a fejlesztésben érintett, Cambridge-ben található kutató-laboratóriumának azévi bezárásától). A program további sorsa nem ismert, az eltelt években újabb típust nem mutattak be, a robotot a Vecna már saját honlapjáról is eltávolította.

ㅎํ A BEAR koncepció a maga módján igen előremutató, azonban egyes kérdéseket nem válaszolt meg (pl.: hogyan biztosítható a sebesült biztos rögzítése, hogyan képes hordágy nélkül gerincsérült mentésére, illetve hogyan tud sebesültet menteni egy épületből ${ }^{4}$ ). Emellett megemlítendő, hogy a medve-fej inkább gyerekjáték vagy szórakoztanyomását kelti (ez valószínűleg nem véletlen, lévén a Vecna ilyen robotokat is kínál).

A BEAR fejlesztése befejeződött, azonban az általa nyert értékes tapasztalatokat felhasználhatják a mentőrobotok új generációjához. A BEAR (és hasonló robotok) a Vecna szerint a mentés mellett más feladatokra is alkalmasak lehetnek: bevethetők ABV fegyverekkel szennyezett területeken, vagy beomlással veszélyeztetett házakban is, sebesültek keresésére, instabil épületek, alagutak felmérésére, veszélyes anyagok szállítására és mentésére. A mentőrobotokat különféle diagnosztikai eszközökkel is felszerelhetik, elősegítve a sebesültek hatékonyabb megragadását, felemelését és kórházba vagy a mentőpáncéloshoz történő eljuttatását. Munkarobotként a lőszerraktárakban lehetne a BEAR-t és utódait felhasználni. További alkalmazási lehetőségként felmerült bevetésük ipari, vagy atomerőmű-baleseteknél, illetve bányaszerencsétlenségnél, de akár a polgári szektorban is, pl. beteg-mozgatásra.

A Vecna mellett más cégek és országok is érdeklődnek a mentőrobotokban rejlő potenciál kiaknázása iránt. Az első ilyen eszköz katonai rendszeresítése és sikeres használata hasonló lavinát indíthat el, mint annak idején a tűzszerész-robotok, illetve az ultrakönnyű felderítő drónok esetében.

\section{FORRÁSOK}

Benjamin Sutherland (szerk.): Modern Warfare,

Intelligence and Deterrence: The Technologies That Are Transforming Them (Wiley, 2012) (2018.02.28.);

Sander Olson interjúja Andrew Allen-nel a BEAR programról (https://www.nextbigfuture.com/2010/09/ organic-polymer-thin-film-could-absorb.html) (2018.02.28.);

Robot Magazin cikke a BEAR rendszerről (https://web. archive.org/web/20101120084734/http://www.botmag. com/articles/04-25-07_vecna_bear.shtml) (2018.02.28.);

The BEAR: Battlefield Extraction-Assist Robot ${ }^{\mathrm{TM}}$ (https:// www.medgadget.com/2007/06/the_bear_battlefield_ extractionassist_robot.html) (2018.02.28.);

Darren Quick: Battlefield Extraction-Assist Robot to ferry wounded to safety (https://newatlas.com/battlefieldextraction-assist-robot/17059/) (2018.02.28.);

Bear robot rescues wounded troops (http://news.bbc. co.uk/2/hi/health/6729745.stm) (2018.02.28.);

Europaische Sicherheit 2008. évi 9. szám;

Strategie und Technik 2008. évi 9. szám;

Technik und Hobby 2010. évi számai;

Y magazin 2010. évi 11. szám.

\section{JEGYZETEK}

1 Hasonló kialakításúak a többek között a Magyar Honvédség által is használt Rheinmetall TeleMAX és Remotec Andros F-6A tüzszerész-robotok is.

2 A DARPA által finanszírozott, lábakon közlekedő BigDog teherszállító robot a teszteken rendkívüli stabilitásról tett tanúbizonyságot, azonban a legújabb, LS3-as robbanómotoros változata müködés közben olyan hangos volt, hogy a teljes programot leállították (tisztán elektromos változat esetében a hasznos teher rendkívül lecsökkent volna). Érdemes azonban megjegyezni, hogy a BigDog kínai másolatának, a Hegyi Négylábú Bionikus Mobil Platform-nak a fejlesztése folytatódik.

3 Többek között az eszköz alumínium vázát acélra cserélték, az elektromos rendszereket ballisztikus lapokkal fedték le, és különböző karokat terveztek a robothoz.

4 A Vecna demonstrációs videóin látható, ahogy az egy manökenbábut szállít, illetve bonyolult csuklós fogókarral kilincset használ, azonban erre egyidejüleg nem képes, lévén a két kar vagy fogóban, vagy emelőlapban végződik és mindkét feladathoz mindkét karra szükség van, ráadásul a zárt ajtón való átjutás sem megoldott. 